\title{
The Establishment of the Russian Intelligence
}

\author{
Antonella Colonna Vilasi \\ Centro Studi University, Rome, Italy \\ Email:ma vil@tiscali.it
}

How to cite this paper: Colonna Vilasi, A. (2018). The Establishment of the Russian Intelligence. Sociology Mind, 8, 123-129. https://doi.org/10.4236/sm.2018.82010

Received: March 12, 2018

Accepted: March 31, 2018

Published: April 3, 2018

Copyright (C) 2018 by author and Scientific Research Publishing Inc. This work is licensed under the Creative Commons Attribution-NonCommercial International License (CC BY-NC 4.0). http://creativecommons.org/licenses/by-nc/4.0/

\begin{abstract}
Intelligence agencies are organized following various models. Contrasting to the "binary" model is the so-called "unitary" which provides a single security service entrusted for both foreign and domestic affairs, as in the case of the famous KGB. It is generally the system preferred from the former Soviet Union and the Warsaw Pact countries. This article evolves around the History of the Russian Intelligence from 1917 to 1925.
\end{abstract}

\section{Keywords}

Intelligence, Russian Intelligence, Politics, Society

\section{Introduction}

Intelligence agencies are organized following various models, which are declined in each and every single State. Contrasting to the "binary" model is the so-called "unitary" which provides a security service competent for both foreign and domestic affairs, as in the case of the famous KGB and it is generally the system preferred from the former Soviet Union and the Warsaw Pact countries.

However, even some countries of the former Soviet bloc adopted the "binary" system and therefore abandoned the unitary one. This article will evolve around the basic facts, events, sociological and political motivations of the first steps of the Russian Intelligence.

With reference to this research, the first question posed is: how was the Russian Intelligence capable of addressing the new challenges posed by the post-revolutionary period?

Second question: what were the new capabilities, know-how and analysis tools

${ }^{\star}$ Pioneer in Intelligence Studies in Italy, the author's research interests focused on Intelligence, the relation with the Political Science and the Intelligence cycle. With more than 70 books published on the topics; among them: The Intelligence cycle, The History of M16, The History of the CIA, The History of the Italian Secret Services, The History of the Entity, The History of Mossad, and the History of the STASI. 
that Intelligence needed in such a new and complex reality as to require a new approach?

\section{Literature Review}

Academic studies, apart from the bibliography proposed in the article, refer mainly to the US, Britih, and East European studies of the sector.

Not to mention Colonna Vilasi (2016). Trilogia di Intelligence, the important essays by Andrew \& Mitrokhin (1999). The sword and the shield: the Mitrokhin archive and the secret history of the KGB and Kaplan (1967), Kaplan System and Process in International Politics, can be stated as undoubtly a milestone in the Intelligence studies of the field.

As far as the Information collection here studied is concerned, it derived from covert sources (from the Defense or other Intelligence agencies), or from Open Source documents like: archives, publications, radio, TV, newspapers, scientific dissertations, and secondary sources as well.

This article can thus be a contribution to the gap in the literature of the field, and its relevance is due to the fact that at the moment the evolution, foundation and the first steps of the Russian Intelligence are not much studied. History and politics texts have different interpretations of the argument, so it is not always easy to know the actual weight and the precise function of Intelligence, especially in the case of the so-called "covert operations". Most likely, it will be the time to help the public opinion to formulate a more precise idea of these scenarios and give an account of the Intelligence operations that lasted for decades and that, despite the criticisms and scandals, still has an important role in the Russian political system.

\section{Research Methods}

This study uses a three-step methodological approach: data collection, coding and analysis, using qualitative techniques.

In particular using a three stage process includes:

- a discovery phase of data collection;

- a coding phase using some of the analytical techniques and proposed methodologies as filters

- an analysis phase using argumentation analysis and Intelligence analysis.

The article offers a number of original contributions to the scientific literature. As regards data sources, data samples, and raw data I refer to the National Archives, Public Record Office, Kew Gardens, Surrey, IK. The series of documents is composed of 70 envelops containing about 3600 documents. It is about secret and top secret documents now open to each and every reader and Open Source.

First, it re-examines the sources and the theory-building and proposes alternatives to the referable scientific literature accepted and proposed by the majority of scholars. 
Secondly, it strengthens the holistic interrelations in terms of consistency between disciplines such as Intelligence studies, history, sociology, political geography, and political science.

The article's mixed methods approach advances a research agenda that addresses potential analytic and cognitive biases that can affect the "at a distance" examination referred to the foundation and the first steps of the Russian Intelligence. A new understanding will emerge on how we can contribute to analysing and understanding the previous and future core of the KGB (Colonna Vilasi, 2016). Thirdly, the proposed mixed methods generate an agenda for possible future studies and researches. The documents used refer to Open Source documents, archives, publications, and reliable secondary sources. The article relies on selected primary sources where possible, and a mixed method, evaluative approach to secondary sources. The crucial gaps in some of the comparative sources are crossed over with newly available sources.

The limitation of this research is due to the fact that it should be treated with an entire volume, and not only with a brief article.

\section{The Establishment of the Russian Intelligence}

After the victory of the October Revolution, the young Russian state found itself in the need to protect its vital interests and to successfully implement a foreign policy (Kaplan, 1967); it was then considered that it was necessary an accurate and complex network of informative structure that could warn in advance of the possibility of an enemy invasion and that the information should be of a strategic nature, and with normal political means it was not possible to obtain information on military secrets or internal politics of a strictly confidential nature, especially because in the 1920s the country did not hold important diplomatic relations with other countries. The first Russian Information Unit was strongly supported by the President of the Russian Extraordinary Commission (CZ), Dzerzhinsky. Before the creation of an independent Intelligence service (Andrew \& Mitrokhin, 1999) Ceka used, in order to carry out reconnaissance and data collection to combat a possible internal and external counter-revolution, other bodies such as the KGB or military counter-espionage according to the needs (the dating of the birth of the KGB is controversial, some sources give 1954, but from the site of the Russian Intelligence it is clear that the KGB, or its primitive structure, was already active immediately after the October revolution).

The agents had to infiltrate the counterrevolutionary oraganizations, especially in the Far East.

During the civil war, it was of utmost importance to infiltrate agents especially in neighboring countries, to promptly discover their plans. Dzerzhinsky was able to convince many people even abroad, who had sympathies for the country, to work secretly for Russia.

It was with the start of the civil war and the foreign intervention of January 6 , 1919 that it was decided, after the creation of the Ceka's special service army, to organize activities of Intelligence, in order to strengthen the fight against the 
counter-revolution and the army's espionage structure. The Intelligence (Madeira, 2018) working abroad in the information gathering was also composed of some special departments and in order to improve the activities of the Foreign Intelligence, in the spring of 1920, the Special Foreign Section of the Ceka created some branches abroad, in which recruited local agents, with a solid cover, required to report cryptographed once a week; with those countries with which there were no agreements, the Intelligence seats were secret, and the agents had no official thread with the Ceka.

It can therefore be said that the Russian Intelligence Service was born from the Ceka in the spring of 1920 (Carter \& Perry, 1999), while in the summer of 1920 the Russian situation, both nationally and internationally, was decidedly complex: the Polish-Soviet war ended with the defeat of Russia, and the long-awaited "miracle on the Vistula" did not happen due to disagreements between Stalin (Feo, 2009) and Trotsky. In fact, the Polish troops occupied the territories of Ukraine and Belarus. It was clear that without an Intelligence structure, the information arrived too late to be useful for an embryonic defense.

The newborn Intelligence Service in September 1920 was reorganized by a Special Commission chaired by Dzerzhinsky, with the Decree of September 20 , 1920, number 169.

The new agency was entrusted with the tasks of:

1) organize and guide agents operating abroad;

2) controlling and possibly combating the activities of the Foreign Intelligence in the national territory;

3) provide passports and visas to agents.

The organizational and personnel structure was ratified by Dzerzhinsky on December 30, 1920.

The structure was as follows:

a) Management Department (the Director, two assistant managers, the special representative for important tasks, the legal counsel, two employees and an associate for instructions);

b) Office Manager (Chief of Staff, his deputy, two senior employees, three juniors, two interpreters and three typists);

c) Undercover Department (Department's Director, his deputy, two commissioners, two employees, a coder, a typist) (Berardi \& Beutelspacher, 1996);

d) Foreign Office (commissioner, Department's secretary, typist);

e) Visa Office, composed of 11 people.

The Ceka had two main tasks:

- Obtain information on the Mensheviks counterrevolutionary organizations abroad and on their agents inside the country;

- Obtaining confidential informationfor the National Security (Aid, 2001).

At the end of the civil war the new country was recognized diplomatically and Russia had to rebuild an economy devastated by war and start a peaceful reconstruction. In 1921 there was a strong political crisis generated by the peasant's 
discontent, caused by the requisitions of the lands that soon turned into a real revolt in some provinces of the country, particularly in the Tambov, which led to some reforms in order to restore security, establishing special measures of control and information (Duroselle, 1998).

On January 23, 1922, the Ceka was abolished and in its place the GPU was born, administratively a section of the People's Commissariat for Internal Affairs (NKVD). Subsequently, in December 1922, after the birth of the Soviet Union that united the countries of the ex Russian Empire, the GPU was transformed into OGPU, which, unlike the previous organizations, also had tasks of political control and justice. These in brief the new tasks of the OGPU:

- identification of the counter-revolutionary terrorist organizations in the neighbouring countries;

- development of Intelligence Departments and counterintelligence;

- processing of political and economic information;

- implementation of measures to divide and discredit the institutions referring to the Menshevik emigration and their leaders.

The first Director of the ISE GPU was Davydov (Davtyan) Hristoforovich Jacob who led the passage and directed the agency in the years 1920-1921, from the end of 1921 until 1922 Mogilev G. Salomone succeeded and from 1922 to 1930 the Director of the ISE was M.A.Trilisser.

In 1922 the OGPU had only 70 employees residing in the territories:

- Nord, which included the Baltic countries and Scandinavia;

- Poland;

- Central Europe (locations in Berlin and London);

- South Europe and the Balkans (based in Vienna);

- Est (Caucasus, Turkey and Iran);

- America (locations in New York and Montreal).

In the years between 1921 and 1925, other offices opened and agents were recruited with solid coverings.

In the 20s the following Foreign Intelligence activities were developed:

- Organizing groups of Russian emigrants and parties;

- Counterintelligence;

- Diplomatic intelligence;

- Economic intelligence.

In 1922, the first Director of the Foreign Intelligence was sent to Beijing, with the role of advisor to the Soviet embassy: Hristoforovich Davtyan, who was also the Director of the ISE in China and who crammed new agents to Beijing, Harbin, Shanghai. In the 1920s the Russian Intelligence implemented various missions, including the one that in code took the name of "Operation Confidence" and that moved the operations also in Helsinki, against the Monarchical Organization of Central Russia (MOTRS), linked to the foreign counter-revolutionaries; finally, the organization was eradicated and the leaders arrested.

We would also like to mention the "Syndicate-2" operation which aimed to hit one of the most active anti-Soviet subversive leaders: Boris Savinkov, closely 
linked to the Polish Intelligence.

The OGPU (Pringle, 2017) decided to lure and arrest him inside the Russian territory. The plan was conceived and implemented successfully, and a fundamental role was played by G. Syroezhkin.

Following Savinkov's arrest, he was replaced by his deputy, Sheshenya, who immediately took steps to re-establish any kind of contact with the anti-Soviet resistors of the "Homeland and Freedom" organization in Minsk and Moscow.

Syroezhkin was sent to Minsk to capture the Minsk's contact, the former captain Gerasimov, and later in Moscow, where he not only captured the contact in that city, but also Sheshenya himself.

Finally, the facts and events herewith described, processed and analyzed illustrate the main point of this article evolving around the need for the young Russian Nation, after the victory of the October Revolution, to protect its vital interests and to implement a Foreign Intelligence.

\section{Conclusions}

Intelligence stories create a sort of thrill and suspense in people's imagination. It is imagined as a spot for secrets and intrigues those are part of phantasy and animate spy novels, films and sitcoms from which ordinary people receive information about Intelligence. Others consider Intelligence as a source of evil, a hidden world of secrecy and deception, in the name of which nefarious acts as political assassinations are carried out. Intelligence professionals have changed a different perspective as they repute Intelligence as a way to get information useful for the political world. To the political leaders Intelligence is a political asset or liability, depending on whether the Intelligence is useful for the fulfillment of the political plans. However perceived, Intelligence evokes strong passions both in proponents and in opponents resulting from the controversial aspects of the foreign policy administration with different points of views and opinions. In any case, Intelligence supports the foreign policy objectives of whichever foreign administration of a country in the international arena. In case the approach is not proper, the main mission (to work side by side with the governmental activity), could be missed.

The article here reported, which is only a part of the extensive literature on Intelligence, takes into account the different topics, insisting on the relationship between the Russian Intelligence and the Government with an internationalist perspective. There is no doubt that the Russian Intelligence sparked several scandals and that the consequences had a strong impact on the international public opinion. There is therefore a strong gap between the popular image of the Intelligence that comes from the fiction and the real one, with many dark areas on how they operate.

\section{References}

Aid, M. A. (2001). Conclusions. In M. A. AID, \& C. Wiebes (Eds.), Secrets of Signals Intelligence during the Cold War and Beyond, Portland: Frank Cass Publishers. 
Andrew, C., \& Mitrokhin, V. (1999). The Sword and the Shield: The Mitrokhin Archive and the Secret History of the KGB. New York, Basic Books.

Berardi, L., \& Beutelspacher, A. (1996). Crittologia. Come proteggere le informazioni riservate. Milano, Franco Angeli.

Carter, A. B., \& Perry, W. J. (1999). Preventive Defense: A New Security Strategy for America. Washington DC: Brookings Institution Press.

Colonna Vilasi, A. (2016). Trilogia di Intelligence. Lecce: Libellula University Press.

Duroselle, J. B. (1998). Storia diplomatica dal 1919 ai giorni nostri. Milano, Edizioni Led.

Feo, A. (2009). Stalin. Milano: Alpha Test.

Kaplan, M. A. (1967). System and Process in International Politics. New York: Wiley.

Madeira, V. (2018). Britannia and the Bear. The Anglo Russians Intelligence Wars, 1917-1929. Suffolk: The Boydell Press.

Pringle, R. W. (2017). Historical Dictionary of Russian and Soviet Intelligence. Lanham: Rowman \& Littlefield Pub Inc. 